\title{
'Let Us Devastate the Avenues Where the Wealthy Live': Resisting Gentrification in the 21st Century City
}

\author{
by Eleanor Wilkinson \\ University of Southampton
}

Sociological Research Online, 21 (3), 2

$<$ http://www.socresonline.org.uk/21/3/2.html>

DOI: $10.5153 /$ sro.4026

Received: 21 Apr 2016 | Accepted: 26 Jun 2016 | Published: 31 Aug 2016

\begin{abstract}
This paper explores why individual retailers have become the target of anti-gentrification protest, examining where the 'blame' for gentrification should be placed. Some commentators have argued that independent retailers should not be scapegoated, as this blames individuals for wider structural processes. In this paper I provide a brief overview of some of the retailers who have been targeted in antigentrification protests. These businesses have been singled out as their aesthetic branding has provoked conflict between existing residents and incoming gentrifiers. In each of these cases, the history of an area has been nostalgically appropriated via ironic marketing campaigns promoting 'hip' urban consumption. The paper questions whether these instances can be simply excused as instances of 'bad taste' and misjudged marketing. I turn to Bourdieu to think about the ways in which class inequality is upheld via symbolic violence. The paper highlights how social inequality does not just come about via economic restructuring, but also through symbolic gestures and lifestyles, which mark certain places as both financially and culturally out of reach. Ultimately, I argue that while the wider structures of gentrification may exist beyond the agency of individual retailers and consumers, this does not mean that individuals have no role to play in determining how gentrification plays out in our communities.
\end{abstract}

Keywords: Activism, Class, Inequality, Protest, Regeneration, Violence

\section{Introduction: No pop-up bars or brioche buns!}

1.1 In September 2015, a group of activists from the anarchist Class War group targeted the Cereal Killer Cafe on Brick Lane, East London [1] Paint and cereal were thrown, and the word 'scum' scrawled across the store window. The attack was part of a larger protest aimed at taking back areas of the capital that had become gentrified. Prior to the protest, the Cereal Killer Cafe had been widely publicized and disparaged across the national press, vilified as an example of the 'hipsterfication' of our streets (Hubbard 2016).[2] The opening of the café even made it onto (Channel 4 news, with reporters challenging the ethics of selling and consuming extortionately priced bowls of cereal in what is one of the poorest boroughs of London. Yet, whilst this demonstration was one of the most widely publicised, it formed part of a much larger body of anti-gentrification protests that have been taking place across the capital. These protests follow decades of gentrification, and the revalorisation of inner-city living by middle-class incomers. It is argued that this return to city-living has often been at the expense of former working class and ethnic communities (Atkinson 2000), producing a number of conflicts and contestations over who has the 'right to the city' (Brenner et al 2002). This paper focuses on why certain retailers have become the target of anti-gentrification protests, exploring where the 'blame' for gentrification should be placed, and questioning whether individual businesses are legitimate targets for those protesting against the social cleansing of the capital. 
that occurs (Christie 2015; Dawson 2015). This viewpoint argues that individual agents are not responsible for gentrification, as they are operating within structures that are not of their own making. From this perspective, blaming the owner of an independent business for the displacement caused by gentrification is to fail to understand the wider laws of capital and property (see Ley 2003). Attacks such as the one by Class War are dismissed as senseless violence directed towards the wrong target. It is argued that 'hipster cafés' are not the cause of social exclusion or poverty; they are merely a symptom of a much deeper problem.

Central to this positioning is the idea that independent retailers are also victims of the gentrification process; that they too are at risk of eventual displacement. Once an area becomes 'fully' gentrified independent small-scale businesses may find themselves unable to compete with the influx of large multi-national chains. Such an argument is founded upon existing academic literature alleging that gentrification unfolds via certain distinct stages. The first stage is when what is termed as 'pre-gentrifiers' move into an area (Rose 1984). These people are typically theorised as 'trendsetters' such as young creative workers who create a 'buzz' around an upand-coming area (Zukin 1982). Once this initial stage is established and an area is seen as vibrant and prosperous, property investors and financial speculators move in to capitalise (Mills 1993). Large-scale residential investment for high-market housing often follows, as well as what Lees (2000) refers to as 'super-gentrification' where international elites seek to create 'gilded ghettos'. It is thus argued that there is a tension between initial gentrifiers - those with high cultural capital yet often low economic capital - and the second-wave of gentrifiers who have high economic capital but lack cultural capital - who are simply buying into a safe sanitised already gentrified area (Ley 2003).

1.4 The tension between these two distinct types of gentrifies is evoked in a statement from one owner of the Cereal Killer Cafe, who claimed that protests such as that by Class War are 'damaging and misguided', commenting that:

If you want to talk about gentrification and different classes, you don't go about attacking independent businesses who are putting their whole life on the line to open a business, you go to the conglomerates and big companies (cited in Khomami \& Halliday 2015)

1.5 The media coverage of this protest frequently noted that the owners of the café were from a working class background, and that they were hard-working entrepreneurs. The then-mayor of London, Boris Johnson (2014), intervened in the debate, claiming that 'we should be hailing anyone who starts a business in this country', they are 'the wealth-creators'.[3] In another interview, one owner of the Cereal Killer Cafe notes that 'targeting small business owners... seems lazy when ... a shiny new Pret A Manger ${ }^{[4]}$ sits at the top of Brick Lane' (Keery 2015). It is hence argued that early-stage gentrifiers, such as those who run independent smallscale businesses, should not be the target of anti-gentrification activism as they too are living a precarious existence. ${ }^{[5]}$ Instead it is proclaimed that the real villain in this story is those who come after the independent trendsetters: the speculative capitalists, the real estate agents, the monotonous high-street chains.[6] However, as Cowen (2006) notes, this division between innocent pre-gentrifiers and dangerous commercial-gentrifiers is no longer quite so clear cut, as hipsters have begun to be institutionalized in the city, working alongside big business and government. The Cereal Killer Cafe exists in a part of London that has already witnessed widespread gentrification. Thus as Cowen notes:

...the fact that hipsters invent themselves in opposition to this competing neoliberalism is no redemption for their violent peace Rather, it gives them a greater evil against which they can see themselves looking even lovelier (2006: 23).

This raises the question as to whether resistance targeted at individual independent businesses should be dismissed as misdirected mindless violence.

\section{The aesthetics of hipster urbanism: ironic nostalgia or symbolic violence?}

2.1 In this section I provide a brief overview of some other retailers who have been targeted by antigentrification protest. These businesses have been singled out as they are seen to have created division and conflict within communities. One such establishment is The Job Centre pub which opened in 2014 in Deptford, South London. Unlike the Cereal Killer Cafe in Shoreditch, which is located in a well established already gentrified area, Deptford still exists on the frontline of gentrification. The pub opened in what used to be the former Job Centre. Despite a campaign to keep the unemployment centre open, it was closed as a result of stringent cuts as part of a broader programme of austerity. The 'ironic' gesture of naming the establishment The Job Centre was seen to be distasteful and offensive to some of the existing residents of Deptford many of whom 
still rely on job centres as a necessary life-line (Elliot 2014). Campaigners noted that there was a food-bank around the corner from The Job Centre, for those low-income residents that struggle financially with their day-today existence. Furthermore, the decision to name a pub The Job Centre must be placed in a wider context: a time when lower-income residents are currently being cleansed from the capital (Lees \& Ferreri 2014;Watt \& Minton 2016). The campaign group Lewisham People for Profit wrote a letter of complaint to the owners of the pub, claiming that the name 'adds the insult of seeing such injuries turned into fun decor for people lucky enough to escape such experience', and that it sends out a 'divisive and repulsive message'. This echoes Zukin's work on the nostalgic re-appropriation of working class culture by those who have no everyday experience of such an existence. As Zukin (1982: 59) notes in her discussion of loft space in New York, '[o]nly people who do not know the steam and sweat of a real factory can find industrial space romantic or interesting'. Likewise, only those who are far removed from the harsh realities of a precarious life of unemployment can enjoy the supposed humour of a job centre themed drinking establishment.

Another attempt to do gentrification 'ironically' can be found in the example of The Advisory, an independent restaurant and bar that opened in 2013 in Hackney, East London. Hackney has undergone significant gentrification, yet is still one of the most deprived areas of London. When The Advisory opened the owners made the decision to keep the original sign from when the building was used as the Asian Women's Advisory Service. To keep up with this theme they also included the use of 'policy announcement' specials boards, and 'advice' themed menus, such as 'please refer to clause 6.4A for advice on how to eat onion rings'. The appropriation of the building's previous use was seen as disrespectful to the vulnerable women of colour who had lost this important community service. An online campaign against The Advisory took place, resulting in the sign being removed from the building, however the 'advisory theme' still continues to date. Establishments such as these stand accused of escalating divisions in local communities, and provoking resentment from existing residents. The mundane harsh lived realities of many urban residents' lives become appropriated via an ironic marketing campaign for 'hip' urban consumption.

2.3 Thus certain independent businesses often show a profound lack of respect for the communities they move into. As a final example we can turn to another business that made the national headlines, The Bonneville, a bar \& bistro, which opened in Hackney, East London. On its first week of opening, a young man ran intoThe Bonneville having suffered a knife attack. The proprietors responded by posting a picture of their blood-stained floor onto Twitter, with the comment 'great look in our first week' alongside the hashtagłwelcometohackney. The young man crossed the boundary between 'us and them': a boundary of respectability. His world impinged on that of the owners, a world they would rather keep out. The body of the young man after a knife attack becomes read solely as an assault on the profitability of a business, his blood staining the hardwood floors condemned as abject, out of place. The poor are unwelcome in this place, it is not a space of hospitality or refuge, it is instead a space of ridicule and class violence. Such disparaging disregard of poorer residents in the neighbourhood falls into a wider societal trend that positions the 'underclass' as 'abject' and 'unruly' (see Skeggs 2011; Tyler 2013).

2.4 What can be made, then, of these three examples? Is it simply a case of 'bad taste' and a misjudgement in marketing, as some commentators have argued? Or could it be read as something more violent? If we think back to the Cereal Killer Cafe protest, the 'senseless violence' of the attack was condemned. However, the violence that takes place through the ironic ridicule of working class and racialised cultures is often far more subtle and difficult to detect. Bourdieu's (1984) concept of symbolic violence highlights the ways in which class violence does not necessarily imply physical violence but rather refers to domination via more subtle forms of misrecognition. As Webb et al (2002: 25) note, symbolic violence takes place when people 'are subjected to forms of violence (treated as inferior, denied resources, limited in their social mobility and aspirations)'. Excusing these establishments on the basis of 'bad taste' ignores the politically violent ways in which taste functions in class conflict.

2.5 The 'ironic' appropriation of the working class former use of a building becomes a form of distinction, which helps create a kind of middle-class habitus. These gentrified retail spaces uphold the consumption norms of a certain kind of middle-class identity. For, as Bridge (2006: 1967) notes, 'residing in neighbourhoods where middle-class visibility and mores are not threatened helps reproduce... objectified and embodied forms of cultural capital'. Therefore, in order to make sure that middle-class 'mores are not threatened' it is essential that these spaces exclude low-income residents. This is done both financially and symbolically. Thus, as Cahill $(2007: 218)$ notes, when we discuss the issue of 'displacement' we should not just focus on the physical displacement of those who have to move out of a neighbourhood, to do so 'loses sight of another dimension of gentrification: cultural displacement'. In Cahill's ethnographic work with young women of colour experiencing gentrification in the Lower East Side of New York, 'gentrification is experienced as a loss of self, community, and culture' (2007: 
219). Cahill highlights the anger and anxiety that this cultural displacement provokes; the feeling you are no longer welcome in the neighbourhood where you once felt at home. The realm of consumption is thus a key site of cultural displacement. Likewise, Paton's (2014: 126) research into working class experiences of gentrification notes the important role consumption can play in the gentrification process, and the ways in which middle-class gentrifiers are often the 'more powerful consumer citizens in the neighborhood'. So as Bourdieu (1984) notes, social exclusion is not just economic, but also has a cultural and symbolic component. Social inequality does not just come about via economic restructuring, but also through symbolic gestures and lifestyles, which mark certain places as both financially and culturally out of reach.

Thus what we are witnessing in London and elsewhere is not just economic restructuring, but a symbolic struggle for the cultural life of neighbourhoods on the frontline of gentrification. If we take into consideration the complex ways in which violence and displacement work, then protests that focus on these cultural symbols of inequality and gentrification can easily be justified. These quotidian experiences of city life are of course linked to broader processes of global capitalist urban restructuring, but these retail establishments are some of the key sites where these tensions are most obviously played out at a local level. They serve as stark visible daily reminders that low-income residents no longer have a place in these neighbourhoods. The aesthetics of new businesses become highly symbolic, synonymous with wider forms of displacement. While all gentrification is a form of violence, it is understandable why many have protested against such establishments, seeing this form of ironic gesturing as one step too far. This symbolic violence is every bit as real as the violence that took place as part of the Class War protest. And while the attack on the insured private property of theCereal Killer Cafe was temporary, the violence committed via gentrification is irreversible.

\section{Conclusion: On ethics \& responsibility}

3.1 In this brief commentary I have focussed on just a few examples of businesses that have become the target of anti-gentrification campaigns. What I have argued then is that there is no reason that independent businesses should be ignored by campaigns against the social cleansing of the city. Claims that we should not attack 'entrepreneurs' and should instead focus on 'big business' or property developers, fail to understand the contemporary logics of urban gentrification, where independent retailers are often no longer just the pre-requisite for gentrification, but are in fact co-existing with big business. To absolve all independent businesses of any responsibility for the violence of gentrification would be misguided.

3.2 As the work of J.K Gibson-Graham $(1996,2006)$ has highlighted, local everyday relations are not simply subject to the wider forces of global capital. Yet as they note, 'the obviousness' of the power of global capitalism 'provides a form of comfort' that is 'difficult to replicate or displace' (Gibson-Graham 2002: 27). We see this kind of logic at work in many of these debates about who is to blame for gentrification, individual local agents are seen as helpless victims to the power of global capital. Yet what would it mean if we revalorized the local as a site of potential power and resistance? How would this affect our understanding of the spaces through which gentrification can be resisted? This re-framing would allow us to see independent businesses and individual consumers as potential agents for resistance and change. For example, each retailer has a choice about the way in which it brands itself, and can seek to do so in a way that respects the location and history of an area. Individual consumers have a choice in what kind of establishments they wish to visit, and can campaign for establishments to do more to support the divided communities in which they reside. What I am arguing then, is that at the very least, an ethics of care needs to be practiced by businesses opening in areas on the frontline of gentrification.

3.3 However, some may argue that focusing on a thoughtless tweet, or the ironic branding of a business, overlooks the 'big issues' of urban inequality: the lack of affordable housing, escalating rents, the rise of foodbanks, speculative housing, and severe cuts to the welfare state. Yet these protests against retailers do not take place in isolation, and are in fact part of a wider network of campaigns against all aspects of gentrification. ${ }^{[7]}$ Prior to the Cereal Killer protest Class War had spent almost a year holding weekly protests outside a property development on Commercial Street in Whitechapel, East London. This block of luxury flats was criticised for its exorbitant 'affordable housing', which developers are required to include in order to gain planning permission. The developers were also critiqued for their use of what has been termed 'poor doors', where those living in designated 'affordable housing' have to enter the building via a separate less salubrious entrance, in order to ensure that the two tiers of residents never have to meet: a visible form of segregation along class lines. Yet this protest received scant media attention. It was only after Class War attacked the world of middle-class consumer culture that people began to take note. 
gentrification solely on multi-national chains, global property developers, and market forces. To do so allows us to absolve our own complicity in the gentrification process. But such attempts to re-focus the blame for gentrification solely on the global corporate elite misses the role of everyday life as a key space of gentrification, and hence a valid site for resistance. Gentrification relies on creating a buzz around an up-and-coming place, upheld by everyday middle class consumer choices and practices. Protest that targets retail gentrification should hence not be dismissed as misguided. Perhaps then, anarchist Lucy Parsons' late nineteenth century rallying call to 'devastate the avenues where the wealthy live' is as relevant as ever.

\section{Notes}

Since the 1970s, the areas around Brick Lane have been a predominantly Bangladeshi area of London, and branded as 'Banglatown'. However, due in part to the proximity to the City of London, gentrification is changing the character of the area and has led to the displacement of working class and ethnic communities

This 'anti-hipster' rhetoric has its root in similar past narratives, such as debates around the 'yuppificaiton' of cities in the 1980s (Smith 1987).

Small-scale start-ups are seen as integral to the British economy. This celebration of the entrepreneur falls into a broader discursive construction of Britain as an 'aspirational nation' (Allen 2014). The owners of Cereal Killer Cafe represent the idea that anyone can work their way out of poverty, that it is possible to climb the social ladder through hard work and entrepreneurial sprit.

Pret-A-Manger is a high-street food outlet chain associated with forms of middle-class consumption.

As noted, the government promotes small-scale entrepreneurial activity as a key pillar of the British economy despite evidence that many such businesses fail, and others are associated with work that is precarious or poorly paid. The rise of small and micro-businesses is of course encouraged by other discourses endemic to neoliberal economies, such as the need to embrace risk, and for flexibility in the face of competition.

Furthermore, this positioning of chain-retailers versus independent-retailers can also play out along deeply classed lines. As Paton (2014) notes in her ethnographic study of working class perspectives on gentrification, resistance to large-scale chains often comes from middle-class residents as large-scale chains are seen as having less cultural value than 'quirky' independent stores.

However, there is also a practical motivation for attacking and targeting individual businesses. For example, consumer boycotts are more likely to have an effect on an independent retailer than a large corporation.

\section{References}

ALLEN, K (2014) Blair's children': young women as 'aspirational subjects' in the psychic landscape of class, The Sociological Review, Vol. 62, No. 4, p.760-779.

ATKINSON, R (2000) Measuring gentrification and displacement in Greater London, Urban Studies, Vol. 37, No. 1, p.149-165.

BOURDIEU, P (1984) Distinction: A Social Critique of the Judgement of Taste.London, Routledge.

BRENNER, N, Marcuse, P \& Mayer, M (2012) Cities for People, not for Profit: Critical Urban Theory and the Right to the City. London, Routledge.

BRIDGE, G (2006) It's not just a question of taste: gentrification, the neighbourhood, and cultural capital, Environment and Planning A, Vol. 38, No. 10, p.1965-1978. [doi:10.1068/a3853]

CAHILL, C (2007) Negotiating grit and glamour: young women of color and the gentrification of the lower east 
side, City \& Society, Vol. 19, No.2, p.202-231. [doi:10.1525/city.2007.19.2.202]

CHRISTIE, B (2015) The Cereal Cafe attackers should seek out the real villains of gentrification,The Guardian, 28/09/15. http://www.theguardian.com/commentisfree/2015/sep/28/cereal-killer-cafe-attackersgentrification-londons-housing

COWEN, D (2006) Hipster urbanism, Relay: A Socialist Project Review, Vol. 13, p. 22-23.

DAWSON, G (2015) Poor fetishes, poor critiques: gentrification as violence, ROAR Magazine, available online at https://roarmag.org/essays/gentrification-critique-structural-violence/.

ELLIOT, J (2014) The Job Centre bar's attempt to do gentrification ironically is an insult,The Guardian, 09/07/14.

GIBSON-GRAHAM, J. K (1996) The End of Capitalism (as We Knew It): A Feminist Critique of Political Economy. Minneapolis, University of Minnesota Press.

GIBSON-GRAHAM, J.K (2002) Beyond global vs. local: economic politics outside the binary frame, in Herod, A, \& Wright, M.W (Eds), Geographies of Power: Placing Scale. Oxford, Blackwell, p. 25-60. [doi:10.1002/9780470773406.ch1]

GIBSON-GRAHAM, J.K (2006) A Postcapitalist Politics. Minneapolis, University of Minnesota Press.

HUBBARD, P (2017) The Battle for The High Street: Retail Gentrification, Class and Disgust Basingstoke, Palgrave Macmillan.

JOHNSON, B (2014) Don't murder the Cereal Killers - we need people just like them, The Telegraph, 15/12/14.

KEERY, A (2015) Our Cereal Killer cafe is spreading joy - protesters should leave us alone, The Guardian, $28 / 09 / 15$.

KHOMANI, N \& Halliday, J (2015) Shoreditch Cereal Killer Cafe targeted in anti-gentrification protests, The Guardian, 27/09/15.

LEES, L (2000) A reappraisal of gentrification: towards a 'geography of gentrification',Progress in Human Geography, Vol. 24, No. 3, p.389-408. [doi:10.1191/030913200701540483]

LEES, L \& Ferreri, M (2016) Resisting gentrification on its final frontiers: Learning from the Heygate Estate in London (1974-2013), Cities, online early doi:10.1016/j.cities.2015.12.005. [doi:10.1016/j.cities.2015.12.005]

LEY, D (2003) Artists, aestheticisation and the field of gentrification, Urban Studies Vol. 40, p.2527- 2544. [doi:10.1080/0042098032000136192]

MILLS, C.A (1993) Myths and meanings of gentrification in Duncan J and Ley D (Eds.) Place/Culture/Representation. New York, Routledge, p. 149-169.

PATON, K. (2014). Gentrification: A working-class perspective. Farnham, Ashgate.

ROSE, D (1984) Rethinking gentrification: beyond the uneven development of Marxist urban theory, Environment and Planning D: Society and Space, Vol. 2, No. 1, p. 47-74. [doi:10.1068/d020047]

SKEGGS, B (2011) Imagining personhood differently: Person value and autonomist working class value practices, Sociological Review, Vol. 59, No. 3., p. 579-594. [doi:10.1111/j.1467-954X.2011.02018.x]

SMITH, N (1987) Of yuppies and housing: gentrification, social restructuring, and the urban dream,Environment and Planning D: Society and Space, Vol. 5, No. 2, p.151-172. [doi:10.1068/d050151]

TYLER, I (2013) Revolting Subjects: Social Abjection and Resistance in Neoliberal Britain.London, Zed Books.

WATT, P and Minton, A (2016) London's housing crisis and its activisms: Introduction,City, Vol. 20, No. 2, p. 204221. [doi:10.1080/13604813.2016.1151707]

WEBB, J, Schirato, T \& Danaher, G (2002)Understanding Bourdieu. Crows Nest, NSW, Sage.

ZUKIN, S (1982) Loft Living: Culture and Capital in Urban Change. Baltimore, MD, Johns Hopkins University 


\section{Press.}

